\title{
Crossing boundaries and facing others: South African perspectives on the transgressive rhetoric of preaching
}

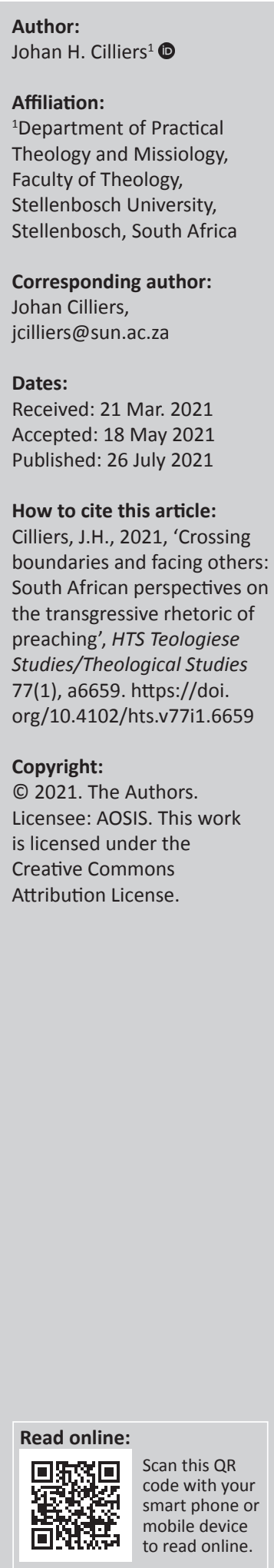

The core question posed by this article is, 'what are the characteristics of a transgressive rhetoric, as evidenced by preaching in South Africa, in particular in view of the transition to democracy, and as based on the African philosophy of Ubuntu?' Or, the other way around, 'what type of (homiletical) rhetoric was in fact needed to achieve the political transition in South Africa?' Cognisance is taken in particular of the rhetorical structures used in this regard by former Archbishop Desmond Tutu, under the headings of inter-facing, interforming and inter-futuring. These rhetorical structures are evaluated in the light of certain rhetorical principles, as expressed in classical Roman oratory.

Contribution: This article traces elements of historical thought and source interpretation by revisiting the particular historical role that former Archbishop Tutu played in the formation of democracy in South Africa, by means of an interpretation of selected writings, i.e. sermons and speeches by the former Archbishop.

Keywords: Desmond Tutu; Ubuntu; rhetoric; preaching; South African democracy; hermeneutics.

\section{Introduction}

The relatively peaceful democratic transition that took place in South Africa in 1994 has been described by many as nothing short of a miracle. A number of reasons for this could be mentioned: for instance, the role of leadership, with iconic figures like Nelson Mandela in the forefront; the influence of dialogue and political negotiations, starting even long before the actual transition; the international pressure on and sanctions of the apartheid government; the therapeutic space that the Truth and Reconciliation Commission created, albeit preliminary and imperfect, and so on.

According to Maphisa (1994:8), 'the transformation of an apartheid South Africa into a democracy is a rediscovery of Ubuntu'. Perhaps one could indeed say that one of the overarching reasons for our peaceful transition was the African philosophy of Ubuntu. In short, it means humanity, or humanness. It arises from the belief that one is a human being through others 'I am because you are' (cf. Ramose 1999:49; Shutte 1993:46). The spirit of Ubuntu has undoubtedly helped us, specifically in the sphere of reconciliation (Van Binsbergen 2003:440). In short, without Ubuntu, there would probably be no 'new South Africa'.

In this article, I will not give a detailed account of the many layers of meaning attributed to the philosophy, or the unmistakeable romanticising, commercialisation, kitschification and even political misuse of Ubuntu (for this, see Cilliers 2010:77-88; see also Cilliers 2017:67-77). My focus will be on the basic point of departure of this philosophy, which in essence could indeed be described as the crossing of boundaries and facing the 'other'. The further delimitation will be preaching as an expression of religious rhetoric in Africa, but also preaching as a distinct transgressive form of rhetoric, as shaped and influenced by Ubuntu. The core question therefore is as follows: 'what are the characteristics of a transgressive rhetoric, as evidenced by preaching in South Africa, in particular in view of the transition to democracy, and as based on the African philosophy of Ubuntu?' Or, the other way around, 'what type of (homiletical) rhetoric was in fact needed to achieve the political transition in South Africa?'

Strictly speaking, although Ubuntu as an African cultural expression could not be called 'theology', there are many prominent theologians who interpret this concept in theological terms. It would be difficult to find a better exponent of Ubuntu than former Archbishop Desmond Tutu, who, for

Note: Special Collection: Historical Thought and Source Interpretation, sub-edited by Johann Cook (Stellenbosch University). 
instance, has developed and practised what could be called a theology of Ubuntu (Battle 1997:5). Tutu's theology is probably one of the most representative expressions of African Ubuntu. For Tutu, Ubuntu has a profound theological meaning, because, in his outspoken view, God has created us to need each other. We are made to be part of a 'delicate network of interdependence' (Battle 1997:35).

In what follows, I venture to describe at least three components of this 'Ubuntu Homiletics', which, in my opinion, is based on what I would call a hermeneutics of inter-flow. These components are inter-facing, inter-forming and inter-futuring. The 'inter' in a hermeneutics of inter-flow refers to spaces (being created) for, and acts of meeting (inter-facing) in view of dialogue. It entails not only an openness to honestly face the 'other', as well as one self, but also a willingness to be transformed in the process, rather than (manipulatively) trying to transform the other, according to pre-set agendas. It rather endeavours the sharing of ideals for the future, and of (re)shaping current realities in order to achieve this envisaged future.

These components of a hermeneutics of inter-flow will also (briefly) be evaluated in the light of what is commonly understood as 'rhetorical principles', as expressed in the rhetorical ethos of Roman oratory (for a summary, see Compier 1999:10-11).

\section{Preaching as inter-facing Rhetorical principle}

In classic understandings of rhetoric, the latter is seen, inter alia, as polemical, even agonistic, with the emphasis on a rhetorical passion for that which is at issue. Cicero often compared the training of the orator with that of a gladiator. According to him, wise rhetors was [sic] always acutely aware of dangers threatening individuals and the state as a whole, and had no other option but to join the rhetorical fray, which added to the inherently combative tenor of the persuasive profession. In this sense, those speaking out on public affairs, could not sidestep its clamour and divisiveness (Cicero 1970, De Oratore, 3.17:210).

A first dimension of preaching as inter-facing would indeed be to literally face one another in order to face the truth. It could also assume the form of a face-off, that is, a 'prophetical' speaking of the truth in the face of the (powerful, threatening) 'other'. When the 'other' is also on the 'other side', there must be a face-to-face, transgressive, rhetorical inter-action, or rather inter-dialogue (the latter of course being a tautology!).

In a remarkable letter, which could in fact be described as a type of 'prophetical sermon, speaking truth to power', and which remained unpublicised for more than three decades, Tutu addressed the then Prime Minister P.W. Botha, and confronted him about the forced separation of white and black people in South Africa in no uncertain terms specifically in terms of the forceful removal of between 2 and
3 million black people from their homes (Tutu 2011:142-147; see also Cilliers 2016:1-13). This letter was written on 05 July 1979 - a time of sociopolitical turmoil in South Africa as seldom experienced before (see Cilliers 2004:161-181; eds. Gilliomee \& Mbenga 2007:330ff.; ed. Müller 1980:510-520). The tension of this catastrophic phase of South African history forms the contextual background of the letter.

In a moving fashion, Tutu appeals not only to P.W. Botha's Christian belief ('as one Christian to his fellow Christian'; Tutu 2011:142), but he makes liberal use of passages of Scripture, and he ends the letter by stating that he will continually pray for P.W. Botha and his colleagues, 'that you may be instruments of his divine gracious will in this beautiful land which we all love so deeply' (Tutu 2011:147). It is exactly within this profound theological framework that Tutu speaks some of his sharpest words of confrontation, of struggling with the system of apartheid (Tutu 2011):

I write to say to you that the policy of population removal and resettlement is quite indefensible on moral and pragmatic grounds... But it is the moral aspect that has shattered me and that I believe you and your colleagues must be unaware of. And it is that human persons are treated as if they are less than that. I must be careful not to use emotive language, but Mr. Prime Minister, I cannot avoid speaking about the dumping of people as if they were things, with little prior consultation about how they felt about things and almost certainly scant attention being paid to how they feel.... I am trying to be as restrained as possible because I want to confess to you that at this moment as I write I am deeply agitated and angered by what I have seen.... We want justice, peace, and reconciliation in our land, and these will come as we strive to remove all which makes people less than what God intends them to be. We will be free together or not at all. (pp. 143-146)

In 2016, in retrospective, I wrote the following, inter alia, concerning this rhetorical outrage and plea of Desmond Tutu (Cilliers 2016):

There seems to be almost something Pauline about this ethical approach and struggle of Tutu: he appeals for change on the grounds of the reality of an identity, in this case - the outspoken Christian belief of P.W. Botha, and that of the whole apartheid government, for that matter. He is agitated and angered, because P.W. Botha and his government are not acting according to the ethical parameters of their so-called Christian confession. This basis of appeal adds theological gravitas to Tutu's analysis of the situation, making it difficult for those who are addressed to ignore it. (pp. 1-13)

At least three characteristics of a transgressive rhetoric can be seen at play here working in unison: firstly, the language of confrontation, of interruption; secondly, the language of consolidation, of integration; and thirdly, the language of rhetorical passion. The link between the seemingly opposite forms of language (of confrontation and consolidation) can be found in the emotive mode - the above-mentioned emphasis on rhetorical passion - in which Tutu speaks, using phrases such as 'the moral aspect that has shattered $\mathrm{me}^{\prime}$, 'I am deeply agitated and angered by what I have seen' and so on. It is from this emotive centre - that is linked to a shared basis of Christianity, and not to be misunderstood as 
emotionalism - that Tutu can confront, but also consolidate; can interrupt, but also integrate.

Although South Africa is a predominantly Christian country (about 77\%), there has always been a plurality of religions, co-existing peacefully next to one another. In our country, one finds a plethora of religious expressions - the Abrahamic (Jewish, Christian and Muslim) tradition, with the African Independent Churches (AICs) being one of these, combined with many Eastern religions and other complex and nuanced strands, representing a mixture of all of these.

In the above instance, Tutu specifically argues on the basis of his and P.W. Botha's Christian beliefs. Many of his ethical stances are however also applicable to other religions and nonChristians. He keeps on insisting that 'God is not a Christian', and that there is a moral core to the universe - of importance for people of all races, but also beliefs (Tutu 2011:3ff.; 206ff.). In the letter quoted above, he also argues on the basis of (supposedly) shared, universal values, that is, the dignity of all human beings, for instance, when he states: 'that human persons are treated as if they are less than that'; 'about the dumping of people as if they were things'; 'all which makes people less than what God intends them to be' and so on. These arguments would have resonated with all the major religions in South Africa, and even the so-called non-religious.

Tutu ironically, or rather in a rhetorical ingenious way, expresses his shock that P.W. Botha and the apartheid government could be guilty of the unthinkable, of not acting, but even worse, not knowing of these moral, universal and Christian values, when he states 'that I believe you and your colleagues must be unaware of'. In short: how on earth could you not know about these matters?

This is transgressive rhetoric - the grammar of the gladiator - at its best.

\section{Preaching as inter-forming Rhetorical principle}

Deliberative oratory accepts that in human affairs decisions can only be reached in a meaningful manner via consensus. All the facts are not yet available, which points towards an inescapable and perpetual state of imperfect knowledge. Through rhetoric there could be a movement towards mutual agreement, which is based on probability, not certainty; informed opinion, not scientific demonstration. (Compier 1999:10)

Facing the other in our search for liberation in South Africa was, and still is, of paramount importance, but even here we should not underestimate the role that power played, and still can play. Inter-facing can easily become a power play - an inter-facing with masks on, the masks of furthering one's own agendas and guarding vested interests. One may face the other without in fact revealing one's true face. In contrast to this (Cilliers 2010):

Inter-facing must take place with the willingness for interforming, the willingness to be fundamentally changed in the process. Inter-facing is not about manipulating the other towards your own image, it is not mere mirroring of one's own face, but of being open to be transformed in the encounter with the other. Inter-facing is not about cloning, but about kenosis, about giving and losing yourself for the sake of the other and, in the process, also finding and discovering yourself. (pp. 77-88)

It is exactly in this regard that Ubuntu comes to our aid: as a cultural philosophy, it affirms unity and at the same time values and endorses diversity. Louw (2002) puts it poignantly:

Ubuntu as an effort to reach agreement or consensus should thus not be confused with outmoded and suspect cravings for (an oppressive) universal sameness, often associated with so-called teleological or 'modernistic' attempts at the final resolution of differences.... True Ubuntu takes plurality seriously. While it constitutes personhood through other persons, it appreciates the fact that 'other persons' are so called, precisely because we can ultimately never quite 'stand in their shoes' or completely 'see through their eyes'. When the Ubuntuist reads 'solidarity' and 'consensus' s/he therefore also reads 'alterity', 'autonomy', and 'co-operation' (note: not 'co-optation'). (p. 11)

In order to achieve the consensus of Ubuntu, you therefore need dialogue and mutual exposure, a genuine reciprocity in which you encounter the difference of the other's humanness so as to inform and enrich your own. This reciprocal space is formed through a respect for the particularity, individuality and historicity of the other (Louw 2002:13f.).

Or, to put it in other words, inter-forming is all about the quality of the 'we'. In this sense, the basis of (shared) Christianity that Tutu employed above is strengthened

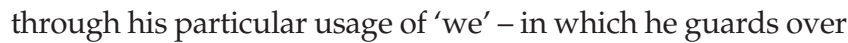
the dignity of all the role-players that constitute this ' $w e^{\prime}$.

Seen against this background of a reciprocal 'we', the prophetical-political preaching of Archbishop Desmond Tutu has been described as being inherently dialogical, as opposed to authoritarian communication. His hallmark has indeed been herrschaftsfreie Kommunikation, a form of communication that operates from the basis of love and compassion as opposed to being judgmental to listeners - even love towards the 'enemy', the oppressor (Pieterse \& Wester 1995:57ff.). In the letter to P.W. Botha, quoted above, this tension is palpable: on the one hand, Tutu expresses anger and indignation; on the other hand, he does not denigrate the humanity or dignity of what could be called his 'enemies'. He even promises to pray for them, given the fact that 'we' share not only certain Christian beliefs, but also this beautiful land called South Africa.

This passion for a true 'we' can be heard throughout the ministry, sermons and writings of Desmond Tutu. In a remarkable sermon on Psalm 77, preached a week before the first general elections in 1994 in South Africa, Tutu (1994), for instance, declared:

You are very special to God. You are of infinite worth to God. God loves you not because you are lovable, but you are lovable precisely because God loves you... Each one of us is of infinite worth because God loves each one of us, black and white, 
with his infinite, everlasting love... For all of us, black and white together, belong in the family of God. We are brothers and sisters, we are one. (pp. 261-263)

Throughout the sermon, one hears this rhetoric of inclusive language, of 'we', of 'black and white together'. As in the following (Tutu 1994):

We are all wounded people, traumatized, all of us, by the evil of apartheid. We all need healing and we, the Church of God, must pour balm on the wounds inflicted by this evil system. Let us declare that we have been made for forgiveness, we have been made for family, that, yes, now we are free, all of us, black and white together, we, the Rainbow people of God! (pp. 261-263)

Indeed:

We will be free together or not at all. (Tutu 2011:143-146)

Of course, Tutu knew that this form of rhetorical bordercrossing and facing the other within the South African context in which he preached could be a risky, even outright dangerous affair. This type of rhetoric can only be believable when we leave our comfort zones and barbed-wired security enclaves, and, in the spirit of kenosis, encounter the victimised and dehumanised other not only to transform their plight, but also to be transformed ourselves.

Tutu knew from our South African experience that 'meaning' could only be found in relationships, specifically also relationships with the seemingly 'meaningless' members of society, the victimised and ostracised - those being treated as less than human. 'Meaning' lies in giving up and giving away, in the enrichment of forming and being formed, in inter-facing that implies inter-forming.

In accordance with the Ubuntu epistemology that underlines the contingency of meaning, however, every achieved 'state of inter-formation' needs to be critiqued ideologically, repeatedly. This we have learnt the hard way (Cilliers 2006):

'Meaning' or 'formation' may never solidify into a monument. During the dark days of apartheid, this is exactly what happened: preaching (of those who sought to supply the 'theological' sanction for apartheid) operated from a fixed and secure biblical 'truth'. It stood above critique and took on the form of a dehumanizing myth that transformed history into nature, and contingency into stringency. (p. 33)

In any endeavour to practise an Ubuntu homiletics, the hermeneutics of inter-flow continuously calls for an openness towards communal interpretation of biblical message(s), in contrast to sermons that offer a single perspective as if it was eternal and unassailable. In this way, inter alia, preaching in post-apartheid South Africa is called upon to demythologise whatever new, destructive myths may appear on the scene. This will have to be an ongoing process, a perpetual practice of a hermeneutics of inter-flow, in which supposed fixed beliefs and notions on all sides of the South African spectrum can be scrutinised and held up to the light.
The biblical text obviously has an important role to play in this scrutiny, but not only in the hands, and through the perspectives, of a select few or an exclusive clan. The ecumenical church, in the broadest sense of the word, also has an important role to play in this regard. In 1994, the birth year of our democracy, I wrote the following about ecumenical hermeneutics (Cilliers 2006):

Within the community of the una sancta catholica there are enriching and controlling powers active like nowhere else. Here, we can continue to hear other voices, the voices of our brothers and sisters, their suffering under, and interpretation of reality, their despair and hope. Here our myths can be relativized, revealed as precisely what they are: human-made constructions for our own prosperity. Here, in the creative cooperation of many interpretation models, our unilateral fixations and omnipotent fantasies can be brought to light... Because, it is especially within the creative play of the ecumene that a hermeneutic of imagination can grow, where we can learn and see concretely in the lives of our brothers and sisters that Scripture does not provide simple answers to our existential, as well as socio-political, questions - but an arsenal of possibilities; that God's will is not locked up in the Bible, theology or in tradition, as in an archive of certainties, but that God's will, indeed, must be sought, namely in the community of believers with their divergent opinions. We need precisely an alternative to our opinion if we want to come closer to the truth. (pp. 71-72)

This seems to me to be truer today than ever before.

\section{Preaching as inter-futuring Rhetorical principle}

In the ethics of Roman oratory, the concern for the safety and health, i.e. future of the commonwealth was of paramount importance. Cicero even referred to the art of rhetoric as a branch of political science, involved in litigation and public policy matters of every sort. In this sense, oratory was a form of praxis, a way of effecting desirable private and public consequences. In short: the art and act of oratory had the future, the shared good for all, in mind. (Compier 1999:10)

For Desmond Tutu, the call towards inter-facing and consequently inter-forming has always been of paramount importance, as indicated above. But the call does not stop here. There is also the need to take the shared values, in particular those that were mutually formed through interfacing and inter-forming further, in view of a shared vision for the future. The role of inter-futuring in fact permeates the rhetoric of Tutu.

'Futuring' is of course a very broad term, but is often used to indicate the shared efforts at exploring the possible scenarios pertaining to the future. It could be described as the act, art or science of identifying and evaluating possible future events. For Tutu this meant to think beyond the inhumanity of apartheid, to imaginatively point towards a society where indeed 'all of us, black and white together, belong in the family of God. We are brothers and sisters, we are one' (Tutu 1994:261-263). 
In a remarkable sermon, preached by Desmond Tutu at the funeral of Steve Biko, his preaching becomes a type of prolepsis of God's promises, a celebration that God is faithful in keeping these promises (Tutu 1983):

There is no doubt whatsoever that freedom is coming. (Yes, it may be a costly struggle still, but we are experiencing today the birth pangs of a new South Africa.) The darkest hour, they say, is before the dawn. We are experiencing the birth pangs of a new South Africa, a free South Africa, where all of us, Black and White together, will walk tall, where all of us, Black and White together, will hold hands as we stride forth on the Freedom March to usher in the new South Africa where people will matter because they are human beings made in the image of God. We thank and praise God for giving us such a magnificent gift in Steve Biko and for his sake and for the sake of ourselves, Black and White together, for the sake of our children, Black and White together, let us dedicate ourselves anew to the struggle for the liberation of our beloved land, South Africa. Let us all, Black and White together, not be filled with despondency and despair. Let us Blacks not be filled with hatred and bitterness. For all of us, Black and White together, shall overcome, nay, indeed have already overcome. (p. 15)

Again, with the rhetorical repetition of 'Black and White together', expressed in a time where the exact opposite was the order of the day, Tutu crosses boundaries and faces others, but in such a manner that he takes his listeners forward, towards the future - a future that has already broken into the present as novum: black and white together 'have already overcome'. This, in my opinion, is inter-futuring, par excellence.

Even in the anger of indignation, as also expressed in the letter to P.W. Botha, we already hear:

'We want justice, peace, and reconciliation in our land' (Tutu 2011:143-146).

Or, in the sermon preached a week before the first general elections in 1994 in South Africa, referred to above (Tutu 1994):

Our God, who makes all things new, will make us a new people, a new united people in a new South Africa. And we can make it - not if we make it but when we make it - it will be because God wants us to succeed, for we will be a paradigm for the rest of the world, showing them how to solve similar problems. Hey, if God be for us who can be against us! (pp. 261-263)

This is a message of liberation by God, which opens up new, often surprising alternatives to the status quo, and so creates hope (Pieterse \& Wester 1995:69-70).

But for Tutu, not only facing one another from across our divides, but also facing a child is the only way in which we can inter-face our future. For him, the future of South Africa has always been linked to this form of inter-facing, that is, to our faces, and in particular to our children's faces. It is no wonder that Tutu often links the future to children. 'When we see the face of a child', he says 'we think of the future. We think of their dreams about what they might become, and what they might accomplish' (Tutu n.d., viewed 08 February 2021, from https: / / www.brainyquote.com / quotes / desmond tutu_454157). For him, the future is tomorrow's child - to borrow a phrase from Rubem Alves. For him, as for Alves, to hope is to hear the melody of this future. Faith is to dance it (Alves 1972:195).

In a playful manner, children imagine and anticipate an alternative world. To be a child is to play. Through their play, children call for new paradigms, and surprising re-configurations - without them knowing it. Through their play, they breathe new life into archaic forms; lifting and shifting that which seems immobilised and immoveable. Exactly for this reason, the dimension of inter-forming is also a gift, given by children. In children, so Tutu argues, the masks and pre-set agendas fall away: 'Children are a wonderful gift. They have an extraordinary capacity to see into the heart of things and to expose sham and humbug for what they are' (Tutu n.d., viewed 28 March 2021, from https://www.brainyquote.com/quotes/desmond_ tutu_403397).

In short, children inter-face in such a manner that they inter-form not only one another but also the future. They are specialists in inter-futuring.

\section{Conclusion}

Desmond Tutu's usage of a rhetoric that advances interfacing, inter-forming and inter-futuring is based on his firm belief in the values of Ubuntu. The linkage and unity between these components can clearly be seen in a speech to the United Nations Commission on Human Rights in Geneva in 2001, when Tutu (2011) stated:

We belong in a world whose very structure, whose essence, is diversity, almost bewildering in extent. It is to live in a fool's paradise to ignore this basic fact... We live in a universe marked by diversity as the law of its being and our being. We are made to exist in a life that should be marked by cooperation, interdependence, sharing, caring, compassion and complementarity. We should celebrate our diversity; we should exult in our differences as making not for separation and alienation but for their glorious opposites. The law of our being is to live in solidarity, friendship, helpfulness, unselfishness, interdependence, and complementarity, as sisters and brothers in one family, the human family, God's family. Anything else, as we have experienced, is disaster... Our survival as a species will depend not on unbridled power lacking moral direction, or on eliminating those who are different and seeking only those who think and speak and behave and look like ourselves... There is room for everyone; there is room for every culture, race, language, and point of view. (pp. 50-52)

It is on these grounds - the inter-dependence of human beings, as envisioned by his Ubuntu theology - that Tutu bases his rhetorical appeals. This represents a rhetoric not of fear for the enemy, but rather acceptance, but even 
stronger than that, a rhetoric of celebration of the crossing of the boundaries, and the encountering of the so-called 'other'.

Tutu invites us to join this circle of celebration. To become like children, again.

\section{Acknowledgements Competing interests}

The author declares that he has no financial or personal relationships that may have inappropriately influenced him in writing this article.

\section{Author's contributions}

J.H.C. is the sole author of this research article.

\section{Ethical considerations}

This article followed all ethical standards for research without direct contact with human or animal subjects.

\section{Funding information}

This research received no specific grant from any funding agency in the public, commercial or not-for-profit sectors.

\section{Data availability}

Data sharing is not applicable to this article as no new data were created or analysed in this study.

\section{Disclaimer}

The views and opinions expressed in this article are those of the author and do not necessarily reflect the official policy or position of any affiliated agency of the author.

\section{References}

Alves, R., 1972, Tomorrow's child. Imagination, creativity, and the rebirth of culture, SCM Press, London.

Battle, M., 1997, Reconciliation: The Ubuntu theology of Desmond Tutu, Pilgrim, Cleveland, $\mathrm{OH}$.

Cicero, M.T., 1970, 'De Oratore', in J.S. Watson (trans/ed.), Cicero on oratory and orators, pp. 209-211, Southern Illinois University Press, Carbondale, IL.

Cilliers, J., 2004, The living voice of the gospel. Revisiting the basic principles of preaching, Sun Press, Stellenbosch.

Cilliers, J., 2006, God for us? An analysis and assessment of Dutch reformed preaching during the Apartheid years, Sun Press, Stellenbosch.

Cilliers, J., 2010, 'In search of meaning between Ubuntu and Into: Perspectives on preaching in post-apartheid South Africa', in M. Lindhardt \& H. Thomsen (eds.) Preaching: Does it make a difference?, Studia Homiletica 7, pp. 77-78, Aros Vorlag, Frederiksberg.

Cilliers, J., 2015, 'Between separation and celebration: Perspectives on the ethicalpolitical preaching of Desmond Tutu', Stellenbosch Theological Journal 1(1), $41-56$

Cilliers, J., 2016, 'Seeing, sighing, signing: Contours of a vulnerable homiletic', Scriptura 115(1), 1-13.

Cilliers, J., 2017, 'Ubuntu or Into? South African perspectives on preaching', in J. Dreyer, Y. Dreyer, E. Foley, M. Nel \& L. Verlag (eds.), Practicing Ubuntu. Practical theological perspectives on injustice, personhood and human dignity, vol. 20 pp. 67-77, International Practical Theology Bd, Lit Verlag, Zürich.

Compier, D.H., 1999, What is rhetorical theology? Textual practise and public discourse, Trinity Press International, Harrisburg, PA.

Gilliomee, H. \& Mbenga, B. (eds.), 2007, New history of South Africa, Tafelberg, Cape Town.

Louw, D.J., 2002, Ubuntu: And the challenge of multiculturalism in post-apartheid South Africa, Zuidam and Uithof, Utrecht.

Maphisa, S., 1994, Man in constant search of Ubuntu: A dramatist's obsession, AIDSA, University of Natal, Piermaritzburg.

Müller, C.F.J. (ed.), 1980, Vyfhonderd jaar Suid-Afrikaanse geskiedenis, Tafelberg, Kaapstad.

Pieterse, H. \& Wester, F., 1995, Desmond Tutu's message, a qualitative analysis, H.J.C. Pieterse (ed.), Kok, Kampen.

Ramose, M.B., 1999, African philosophy through Ubuntu, Mond Books, Harare.

Shutte, A., 1993, Philosophy for Africa, UCT Press, Rondebosch.

Tutu, D., 1994, The rainbow people of God: The making of a peaceful revolution, J. Allen (ed.), Doubleday, New York, NY.

Tutu, D., 2011, God is not a Christian. Speaking truth in times of crisis, Rider, London.

Tutu, D.M., 1983, Hope and suffering. Sermons and speeches, Skotaville Publishers, Johannesburg.

Van Binsbergen, W.M.J., 2003, Intercultural encounters, African and anthropological lessons towards a philosophy of interculturality, Lit Verlag, Münster. 